Małgorzata Kłys, Sebastian Rojek, Martyna Maciów-Głąb, Karol Kula

\title{
Alkaloidy opium w toksykologicznej praktyce medyczno-sądowej Zakładu Medycyny Sądowej UJ CM
}

Opium alcaloids in toxicological medico-legal practice of Department of Forensic Medicine, Jagiellonian University Medical College

Z Katedry Medycyny Sądowej UJ CM

Kierownik: prof. dr hab. n. med. M. Kłys

Opiaty są uważane za najstarsze narkotyki znane w historii ludzkości. Na przestrzeni wieków, zmieniato się spojrzenie na problem narkomanii, tworzyły się wieloaspektowe obszary badawcze. Współczesna narkomania stanowi przede wszystkim problem społeczny i kliniczny, obejmując swym zasięgiem między innymi, ratownictwo w zatruciach i leczenie uzależnień. Z drugiej strony, jest to także problem wymiaru sprawiedliwości, realizującej zasadę trafnej represji w przypadkach kryminalnych (gwałty, rozboje, kierowcy, produkcja narkotyków i handel) oraz konieczność monitorowania zgonów związanych z narkotykami.

Możliwości badawcze we wszystkich przypadkach mające związek z narkomanią wzrosły wraz z wprowadzeniem i rozwojem niezwykle czułych i specyficznych metod analitycznych (GC-MS, LC/MS, HPLC/DAD), umożliwiających wykrywanie i identyfikację wieloskładnikowych mieszanin ksenobiotyków w złożonych matrycach biologicznych na niskim poziomie stężeń.

Historia krakowskiego Zakładu Medycyny Sądowej sięga roku 1877, gdyż od tego czasu przechowywany jest materiał archiwalny. Pojedyncze zgony w wyniku zatrucia morfiną dotyczące głównie pracowników służby zdrowia były przedmiotem ekspertyz medyczno-sądowych od początku XX wieku, ale dopiero lata 1980-te przyniosły zapotrzebowanie na wielokierunkowe badania toksykologiczne opiatów oraz ich metabolitów w zróżnicowanym materiale biologicznym i nie biologicznym. Niniejsza praca jest specyficznym raportem z opublikowanych prac dotyczących badań nad opiatami w materiale krakowskiego Zakładu Medycyny Sądowej.
Most likely, opium was the first narcotic substance discovered at the dawn of mankind. Contemporary drug abuse predominantly poses a social and clinical problem and encompasses among other aspects emergency procedures in cases of intoxication and treatment of addictions. On the other hand, this is also a problem of the judicial system, which implements the rule of apt punishment in criminal cases (rapes, robberies, drivers, production and trade in narcotic substances) and of the necessity of monitoring drug-associates deaths.

In all drug-associated cases, investigative capabilities have increased with the introduction of extremely sensitive and specific analytical methods (GC-MS, LC/MS, HPLC/DAD) allowing for detection and identification of multi-component mixtures of xenobiotics found at low concentration levels in complex biological matrices.

The history of the Krakow Department of Forensic Medicine dates back to the year 1877, since archival materials have been kept since that time. Isolated deaths resulting from morphine poisoning, mostly involving individuals employed in the health care sector, constituted the subject of medico-legal expert opinions starting at the beginning of the $20^{\text {th }}$ century, but only the eighties did bring the need for multidirectional toxicological examinations of opiates and their metabolites in diversified biological and non-biological materials.

The present report, in addition to the historical background of opiate addiction, discusses selected problems derived from published by Department reports on opiates, including cases of fatal intoxication, hair analysis of drug addicts in its various aspects, interactions in cases of poisoning and others. 
Słowa kluczowe:

opiaty, morfina, heroina, glukuronidy

Key words:

opium, opiates, morphine, heroin, glucuronides

Współczesna narkomania na świecie i Polsce ma wieloaspektowy charakter. Z jednej strony stanowi problem społeczny i kliniczny, obejmując swym zasięgiem między innymi ratownictwo w zatruciach i leczenie uzależnionych. Z drugiej strony, jest to problem wymiaru sprawiedliwości realizującej zasadę trafnej represji w przypadkach kryminalnych (gwałty, rozboje, kierowcy, produkcja narkotyków i handel) oraz konieczność monitorowania zgonów mających związek z narkotykami.

Specyficzną cechą opiatów jest zdolność do wywoływania błogostanu, oszołomienia a nawet kolorowych wizji, odsuwania problemów życiowych na plan dalszy. Ich zażywanie pod różnymi postaciami szybko prowadzi do zależności fizycznej i psychicznej, co skutkuje uszkodzeniami somatycznymi i psycho- degeneracyjnymi osobowości oraz uszkodzeniami mózgu z objawami charakteropatycznootępiennymi [1,2].

Według mało precyzyjnych informacji ostatnich lat, liczbę narkomanów opiatowych zarejestrowanych w lecznictwie stacjonarnym w Polsce szacuje się na poziomie powyżej 4000, jednakże liczbę osób uzależnionych od opiatów ocenia się na 300000-50000 osób, gdyż do szpitala trafia zaledwie co dziesiąty narkoman [3].

Całkowicie osobny problem stanowi opiniowanie sądowo-lekarskie przypadków śmiertelnych mających związek z narkotykami. W archiwum Zakładu Medycyny Sądowej UJ CM przechowywane są protokoły wszystkich sekcji zwłok wykonanych tam od 1877 roku, będące niezwykle prawdziwym i przez to cennym źródłem informacji. W ostatnich dziesiątkach lat liczba zatruć śmiertelnych rozwiązywanych w krakowskim Zakładzie wynosiła 10-15\% przy liczbie sekcji zwłok na poziomie 1000. W starych protokołach sekcyjnych z okresu międzywojennego najczęściej spotykane były zatrucia morfiną i strychniną, a sporadycznie także kokainą. Morfina pod postacią nalewki makowej czyli Tinctura opii była lekiem o dość ograniczonym dostępie, stąd większość zatruć dotyczyła pracowników służby zdrowia - aptekarzy, lekarzy, pielęgniarek.
Interpretacja zatruć narkotykami miała znacznie skromniejszy zakres w porównaniu ze współczesnością. Opierała się na analizie jakościowej w reakcjach chemicznych z detekcją barwną. Pierwsza reakcja jakościowa na wykrywanie morfiny w moczu była znana na początku XIX wieku: „Metodą Stas-Otto uzyskano wyciąg z rozczynem alkalicznym z $\mathrm{NH}_{3}$ za pomocą alkoholu amylowego, który z kwasem siarkowym się nie barwił, z $\mathrm{HNO}_{3}$ barwił się przemijająco krwistoczerwono, potem żółto. Wyciąg krystaliczny zawieszony z HCL rozcieńczonym solą z dodatkiem obojętnego $\mathrm{Fe}_{2} \mathrm{Cl}_{6}$ barwi się niebiesko, potem zielono" [4]. Taki dokument należy już do historii, musiało minąć ponad 100 lat, aby analityka toksykologiczna ukazała inne oblicze.

Problematyka na polu opiniowania sądowo-lekarskiego dotycząca przypadków osób żywych i w przypadkach ze skutkiem śmiertelnym wytworzyła kilka obszarów badawczych, koncentrujących się na rozwiązywaniu następujących kwestii:

1. Problemy metodologii badawczej:

a) wybór metod analitycznych nakierowanych na procedurę przesiewową (FPIA, ELISA, inne) oraz wysoce selektywnych referencyjnych (HPLC/DAD, LC-MS-MS, GC/MS) wraz z ich walidacją,

b) wybór materiału do badań, obejmujący materiał niebiologiczny (susze roślinne, proszki, płyny), materiał biologiczny podstawowy i alternatywny od żywych i ze zwłok,

c) opracowanie procedur obróbki materiału (izolacji ksenobiotyków), ocena tła biologicznego w aspekcie interpretacji wyników.

2. Identyfikacja środków odurzających w suszonych makowinach w aspekcie ustawy o przeciwdziałaniu narkomanii.

3. Wykorzystanie analizy morfiny i jej metabolitów - glukuronidów - w interpretacji wyników do celów opiniowania sądowo-lekarskiego.

4. Wykorzystanie analizy włosów osób żywych w aspekcie ustalania profilu uzależnienia i abstynencji w programie metadonowym leczenia uzależnienia opiatowego.

5. Interpretacja wyników oznaczania ksenobiotyków w materiale biologicznym podstawowym i alternatywnym w aspekcie przyczyny śmierci.

6. Problemy interakcji w powiązaniu z opiatami.

W okresie powojennym, w latach 1946, 1955, 1960 wśród lekarzy pojawiły się pierwsze, poje- 
dyncze zatrucia morfiną [5]. Ale dopiero w ostatnich trzech dekadach tj. po roku 1980 nastąpił okres, w którym notowano przypadki zatruć śmiertelnych opiatami, $\mathrm{z}$ reguły $\mathrm{w}$ interakcji z lekami oraz innymi narkotykami - kokainą, amfetaminą, kannabinoidami. Polska narkomania tego okresu charakteryzowała się brakiem na czarnym rynku czystej morfiny i wysokojakościowej heroiny. Głównym źródłem tego typu narkotyków były i są nadal przetwory surowca roślinnego - słomy makowej i mleczka makowego. Liczbę przypadków rozwiązywanych na przestrzeni tego okresu w krakowskim Zakładzie trzeba szacować na około 150, w tym około 30\% osób żywych w aspekcie odpowiedzialności karnej, resztę stanowiły zgony w wyniku przedawkowania (statystyka Zakładu Medycyny Sądowej UJ CM).

Na przestrzeni ostatnich dekad obserwuje się znaczące i korzystne zmiany w zakresie wyposażenia aparaturowego laboratoriów diagnostycznych. Postęp techniczny stworzył ogromne możliwości wykorzystania technik analitycznych do detekcji, identyfikacji i określania ilościowego ksenobiotyków w matrycy biologicznej. W latach 60-tych i 70-tych przeciętne laboratorium toksykologiczne było wyposażone w spektrofotometr pracujący w zakresie światła UV-VIS, a metoda chromatografii cienkowarstwowej (TLC) była podstawową techniką w identyfikacji trucizn organicznych. Proste w swej konstrukcji chromatografy gazowe, jakkolwiek wyposażone $w$ rozmaite detektory (FID, AFID, TID, ECD) czy też cieczowe z detektorem UV, DAD lub rzadziej elektrochemicznym, rzucały na analitykę pierwsze światło nowoczesności. W późniejszym czasie lawinowy rozwój tych technik doprowadził na przełomie wieków XX i XXI do powstania metod referencyjnych poprzez konstrukcję wysoce selektywnych i czułych chromatografów gazowych i cieczowych z detektorami mas (LC-MS-MS, GC-MS-MS), rozbudowanymi technicznie, całkowicie zautomatyzowanymi i skomputeryzowanymi. Najnowsze metody referencyjne w chwili obecnej pozwalają uzyskać wyniki o 100\% wiarygodności. Na bazie tych metod powstały ciągle poszerzane i uzupełniane bazy danych.

Równoległy trend rozwojowy na polu metodyki badawczej wytworzył pulę metod przesiewowych testów, bazujących na szybkich detekcjach barwnych, immunochemicznych czy immunofluorescen- cyjnych (FPIA). Metody te są niezwykle przydatne we wstępnej fazie badania toksykologicznego, a ponadto ważne do celów szybkiej diagnostyki klinicznej oraz wstępnej fazy kwalifikacji czynu zabronionego (policyjna kontrola drogowa, wypadek komunikacyjny). Do ich zastosowania stosuje się płyny ustrojowe wprost, a więc nie jest konieczna izolacja ksenobiotyków z materiału biologicznego, wynik uzyskuje się w ciągu nawet kilku minut. Charakteryzuje je wysoka czułość, ale niska selektywność i tym samym niska wiarygodność. Stąd też każdy wynik dodatni musi być zweryfikowany przy pomocy metod referencyjnych $[6,7]$.

Mając dostęp do metod analitycznych należy dokonać wyboru materiału badawczego, którym może być materiał niebiologiczny i biologiczny. Materiał niebiologiczny obejmuje dowody rzeczowe, takie jak susze roślinne, zawierające określone stężenia substancji czynnych ( $\Delta$ 9-THC w konopiach, morfina w makowinach), proszki, tabletki, płyny. Obecność substancji czynnych w dowodach rzeczowych rozpatrywana jest $w$ aspekcie ustawy o przeciwdziałaniu narkomanii (Ustawa z 29 lipca 2005 o przeciwdziałaniu narkomanii (Dz.U. Nr 179, poz.1485 z poźn.zm), a także może wskazać kierunek dalszych etapów właściwej ekspertyzy.

W praktyce toksykologicznej medyczno-sądowej stosuje się materiał biologiczny podstawowy od osób żywych - krew, mocz - oraz alternatywny - ślinę, włosy. Materiał biologiczny pośmiertny podstawowy obejmuje krew, mocz, wątrobę, rzadziej nerkę, zaś materiał alternatywny obejmuje żółć, płyn mózgowo-rdzeniowy, płyn z gałki oka, limfę ucha oraz włosy.

We wstępnej analitycznej procedurze czyste płyny ustrojowe pobrane od żywych (ślina, mocz, pot) czy od zmarłych (płyn mózgowo-rdzeniowy, płyn z gałki oka, mocz), nie wymagające obróbki chemiczno-toksykologicznej poddawane są testom przesiewowym. Pozostały materiał, zarówno podstawowy jak pośmiertny, wymaga obróbki chemiczno-toksykologicznej celem otrzymania analitów, a następnie ich badania $w$ dalszej procedurze toksykologicznej, zmierzającej w kierunku detekcji i oznaczenia odpowiednich ksenobiotyków.

Liczba zbadanych dowodów rzeczowych w Zakładzie Medycyny Sądowej UJ CM w postaci suchych makowin sięgała kilku setek w ostatnim 30-leciu. Ich ocena zmierzała w kierunku określe- 
nia w nich morfiny w świetle ustawy o przeciwdziałaniu narkomanii. Zawartość morfiny powyżej $0.06 \%$ suchej masy rośliny wskazywała na kwalifikację objętą kontrolą ustawową, wyznaczając granice konsekwencji prawnych dla posiadacza takiego towaru.

Analizując materiał pochodzący od osób zarówno żywych jak i zmarłych próbowano ustalić profil uzależnienia polskich narkomanów, który jak się okazało charakteryzował się obecnością składników opium, głównie morfiny, w mniejszym stopniu innych alkaloidów opium. W wielu przypadkach zgonów wykrywano w moczu, rzadziej we krwi, 6-MAM w dość niskich stężeniach, traktowanej jako markera „kompotu”, zawierającego pewne ilości heroiny. W profilu uzależnienia pojawia się także amfetamina, w pewnym odsetku rozmaite leki, głównie benzodiazepiny $[6,7,8]$.

Analizując zawartość morfiny we krwi osób żywych i zmarłych uzyskano przedziały stężeń w dość szerokim zakresie. O ile poziom morfiny we krwi u osób zażywających morfinę do celów klinicznych był istotnie mniejszy w porównaniu z poziomem w zatruciach bez skutku śmiertelnego, to zakresy stężeń $w$ zatruciach śmiertelnych mieściły się w bardzo szerokim zakresie $0.02 \mathrm{mg} / \mathrm{l}$ - 4 mg/l, pokrywając zakres wszystkich typów przyjmowania opiatów. Uzyskiwane przez nas wyniki w tym zakresie pokrywały się z wartościami liczbowymi w granicach uzyskiwanych przez innych badaczy, zamieszczanymi w publikowanych bazach danych [9, 10].

Analiza dużej liczby przypadków śmiertelnych w wyniku zatrucia pozwoliła na obserwację, że ostateczny efekt toksyczny zależy od wielu czynników, stąd tak duży zakres stężeń we krwi sekcyjnej zmarłych. Nie bez znaczenia był efekt uzależnienia. Spotykano zgony po podaniu relatywnie niewielkiej dawki „kompotu” osobie będącej w fazie abstynencji, co wiązało się najprawdopodobniej z obniżeniem tolerancji na opiaty. W przypadkach, w których wykrywano kilka rodzajów ksenobiotyków, zgon miał miejsce najprawdopodobniej w późnej fazie eliminacji i w związku z tym wykazywano bardzo niskie stężenia ksenobiotyków. Także w przypadkach powiązanych z etanolem doniosłą rolę odgrywa wzmożone działanie depresyjne leków narkotycznych i alkoholu na ośrodkowy układ nerwowy. Wypicie alkoholu z morfiną powoduje wzrost wrażliwości organizmu na morfinę i odwrotnie. W zejściach śmiertelnych wtedy stwierdzano zawartość morfiny na niskim poziomie stężeń.

Oznaczenie alkaloidów opium w innych materiałach alternatywnych, takich jak płyn mózgowo-rdzeniowy, a zwłaszcza żółć, wniosło natomiast pewne dodatkowe informacje na temat mechanizmu toksyczności opiatów [8]. Duże znaczenie w ocenie toksyczności opiatów mają metabolity. Stwierdzono, że glukuronidowy metabolit morfiny (M6G) wykazuje duże powinowactwo do opioidowego receptora. Po wielu dawkach morfiny M6G ulega kumulacji, co czyni go odpowiedzialnym za przeciwbólowy efekt działania morfiny [11]. Z kolei M3G nie wiąże się z receptorami, nie ma właściwości przeciwbólowych, jest odpowiedzialny za uboczne efekty działania morfiny i bierze udział w tworzeniu tolerancji na opiaty.

Badania w materiale własnym na kilku przypadkach, wzbogacone danymi eksperymentalnymi innych autorów $[12,13]$ pozwoliły na wnioskowanie dotyczące klasyfikacji mechanizmu zgonów użytkowników wysokogatunkowej heroiny oraz „kompotu" w wyniku przedawkowania opiatów. Wykorzystanie oznaczania metabolitów w interpretacji wyników dotyczących żywych i zmarłych biorców heroiny i morfiny może stanowić interesujące narzędzie, pomocne w interpretacji wyników do celów orzecznictwa sądowo-lekarskiego.

Okazało się, że chroniczne zażywanie heroiny prowadzi do wzrostu stężenia M6G, rozważa się w takich przypadkach także możliwość niekorzystnego wpływu heroiny na proces glukuronizacji morfiny. Wysokie stężenia M6G stwierdzono u chronicznych narkomanów heroinowych, którzy nie porzucili nałogu przyjmowania heroiny pomimo podjęcia terapii metadonowej. Zauważono ponadto, że wysoka koncentracja 6-MAM oraz wysoki stosunek ilościowy morfiny (M) i M6G mają pewne znaczenie w ocenie czasu, jaki upływa od przyjęcia wysokiej dawki heroiny do efektu przedawkowania. Korelacje wzajemnych relacji M6G/M, M3G/M oraz M3G/M6G mogą stanowić praktyczne narzędzie do różnicowania zgonów w wyniku przedawkowania heroiny w kategorii „rapid death” (niska M6/M, częsta obecność 6-MAM) oraz „delayed death" (wysokie M6/M, brak 6-MAM). Wieloparametrowe przedawkowanie, obejmujące wiele ksenobiotyków z reguły prowadzi do „delayed death" [14]. 
Interesującym aspektem badań była analiza włosów, pobranych od osób uzależnionych od opiatów. Uzależnienie od heroiny przyjmowanej przez palenie lub iniekcje może być identyfikowane przez obecność 6-MAM oraz morfinę, jako metabolit heroiny w organizmie. Zarówno morfina jak i 6-MAM mogą łatwo penetrować w strukturę włosa, stąd mogą być dowodem przyjęcia heroiny. Stosunek ilościowy ponadto 6-MAM/M we włosach większy niż 1.3 wskazuje na przyjęcie wysoko gatunkowej heroiny. Badanie kilku próbek włosów od polskich opiatowców oraz pochodzących z zachodniej Europy pozwoliły na wyznaczenie różnic w profilu uzależnienia. We włosach tych ostatnich wykazano wysokie wskaźniki 6-MAM/M (4.9-7.4) co przemawiało za przyjmowaniem wysoko stężonej heroiny, podczas gdy powyższa relacja w przypadku polskich narkomanów była znacznie poniżej 1.0, co jednoznacznie potwierdzało znane opinie o przyjmowaniu przez nich polskich produktów makowych typu „kompot” o niskiej zawartości heroiny. Różnica w profilu uzależnienia obu grup badanych wskazała na kokainę towarzyszącą europejskim heroinowcom, podczas gdy polscy narkomani biorą obok kompotu amfetaminę i w pewnych przypadkach także leki (benzodiazepiny, paracetamol, aspiryna) $[15,16]$.

Interesującym aspektem badań na polu opioidów była analiza włosów osób uzależnionych od opiatów, leczonych w programie metadonowym, które miały na celu ocenę wymaganej abstynencji od narkotyków u leczonych. Oznaczano we włosach metadon oraz jego metabolit, a także obecne równolegle w próbkach opiaty, amfetaminę, leki, co wskazywało na profil uzależnienia. Analiza próbek włosów pobranych od 20 osób, zakwalifikowanych do badania, wyrywkowo z dużej grupy pacjentów leczonych wykazała, że tylko $1 / 3$ z nich zachowywała całkowitą abstynencję, 1/3 powstrzymywała się od zażywania opiatów, ale pozostawała przy amfetaminie, zaś $1 / 3$ nie stosowała żadnej abstynencji, traktując metadon, jako dodatkowy narkotyk [17]. Brak abstynencji skutkuje wykluczeniem z programu, z uwagi na niebezpieczeństwo przedawkowania, a także ze względów formalnych.

W przypadkach śmiertelnych analiza włosów stanowi element uzupełniający materiał badawczy, może wykazać, potwierdzić lub wykluczyć uzależnienie od narkotyków, a także pomóc w ustaleniu mechanizmu i przyczyny śmierci. W jednym z przypadków dotyczącym śmierci młodej kobiety, we krwi sekcyjnej wykazano niskie stężenia morfiny i kokainy, co nie dawało podstaw do hipotezy przyczyny śmierci wskutek przedawkowania tych ksenobiotyków. Badanie mikroskopowe natomiast wykazało zmiany w narządach wewnętrznych, szczególnie w płucach i sercu, sugerując zgon wskutek powikłań, mogących mieć związek z zażywaniem heroiny i kokainy. Jednakże dopiero analiza włosów pozwoliła postawić przysłowiową "kropkę nad i". Wskazując na profil uzależnienia od kokainy (obecność kokainy i benzoylecgoniny) i heroiny (6-MAM) w okresie co najmniej 8 miesięcy poprzedzających zgon (8 cm kosmyk włosów), tłumaczyła tym samym obecność nabytych zmian w narządach, wykazanych w badaniu histopatologicznym. Przyjęto hipotezę zgonu przypadkowego kobiety wskutek powikłań, wynikających z długiego przyjmowania tych narkotyków [18].

Analiza błędu medycznego diagnostycznego, w wyniku nadinterpretacji przesiewowego badania w kierunku obecności opiatów u pacjenta, dopełnia szerokiego obszaru badawczego podjętego zagadnienia [19]. W rozważanym przypadku doszło do błędnego rozpoznania przedawkowania opiatów u 13-letniego chłopca zamiast schorzenia neurologicznego, na skutek zlekceważenia przez lekarza istotnych symptomów choroby neurologicznej i przyjęcia w to miejsce subiektywnych podejrzeń w kierunku zatrucia opiatami. Podstawą takiej diagnozy było badanie moczu, w którym wykazano w teście immunochemicznym obecność opiatów. Pomimo braku symptomów klinicznych zatrucia opiatami oraz informacji matki chłopca o zażywaniu leku Tiocodin ze względu na przebytą infekcję dróg oddechowych, lekarz zawierzył obiegowym opiniom, że wszystkie nastolatki „biorą", nie podejmując właściwych decyzji klinicznych w kierunku diagnozy i leczenia schorzenia neurologicznego. Skutki takiej niefrasobliwości w postaci niepełnosprawności chłopca, a także urazów w znaczeniu psychologicznym i społecznym w sposób istotny zaważyły negatywnie na rozwoju młodocianego.

Dyskusja na temat narkotyków i ich roli w społeczeństwach świata nigdy się nie kończy, jakkolwiek z czasem przekształca swoje oblicze. Historia dotycząca opiatów tego dowodzi [20]. Angielski lekarz Andrew Weil w swojej pracy The Natural 
Mind, 1973 przyznaje wprawdzie, że narkotyki mogą „zaszkodzić ciału, zaszkodzić umysłowi, zahamować wszelki rozwój”, ale próbuje tłumaczyć „,biorących narkotyki" istnieniem wielu powodów, dla których ryzyko takie można podjąć i zaspokoić jed-

\section{PIŚMIENNICTWO}

1. Szukalski B.: Narkotyki. Kompendium wiedzy o środkach uzależniających (Narcotics. Compendium of knowledge about drugs of abuse). Instytut Psychiatrii i Neurologii. Warszawa 2005.

2. Robson P. H.: Narkotyki (Forbidden drugs: Understanding drugs and why people take them). Medycyna Praktyczna. Kraków 1997: 137-159.

3. Habrat. www.medox.or.pl

4. Konopka T.: Rozwój tanatologii sądowej w świetle analizy protokołów sekcyjnych Zakładu Medycyny Sądowej Uniwersytetu Jagiellońskiego. Arch. Med. Sąd. Kryminol. 2011, 61 (3): 203-302.

5. Kłys M., Baran E.: Zatrucia śmiertelne w materiale Zakładu Medycyny Sądowej w Krakowie w latach 1946-1995. Arch. Med. Sąd. Kryminol. 1996, 46 (4): 277-287.

6. Kłys M., Klementowicz W., Trela F.: Wybrane problemy orzecznictwa medyczno-prawnego w zatruciach substancjami uzależniającymi. Przeg. Lek. 1997, 54: 404-409.

7. Kłys M., Klementowicz W., Bujak-Giżycka B., Kołodziej J., Trela F.: Opiniowanie sądowo-lekarskie w narkomanii w świetle nowoczesnej analityki toksykologicznej. Przeg. Lek. 2000, 57: 272-576.

8. Kłys M.: Problemy orzecznicze i metodyczne w zatruciach śmiertelnych opiatami. Arch. Med. Sąd. Kryminol. 1996, 46 (3): 177-185.

9. Moffat A. C., Osselton M. D., Widdop B. (ed.): Clarke's Analysis of Drugs and Poisons. Pharmaceutical. Great Britain 2004. Ch.8. Kintz P. Hair Analysis: 124-134.

10. Baselt R. C.: Disposition of toxic drugs and chemicals in man. $5^{\text {th }}$. edn. Chemical Toxicology Institute, Foster City.: 407-412.

11. Portenoy R. K., Khan E., Layman M. et al.: Chronic morphine therapy for cancer pain: plasma and cerebrospinal fluid morphene and morhine-6glukuronide concentration. Neurology. 1991, 41: 1457. ną z podstawowych potrzeb człowieka, jaką jest doznanie odmiennych stanów świadomości [2]. Ale tutaj już przekraczamy granice toksykologii i wkraczamy w inny obszar badawczy, który rozważa sferę wolności człowieka.

12. Bogusz M. J., Maier R. D., Erkens M., Driessen S.: Determination of morphine and ist 3and 6-glucuronides, codeine, codeine - glucuronide and 6-monoacetylmorphine in body fluids by liquid chromatography atmospheric pressure chemical ionization mass spectrometry. J. Chromatography B. 1997, 703: 115-127.

13. Aderjan R., Hofman S., Schmitt G., Skopp G.: Morphine and morphine glukuronides in serum of heroin consumers and heroin-related deaths determined by HPLC with native fluorescence detection. J. Anal. Toxicol. 1995, 19: 163-168.

14. Kłys M., Rojek S.: Four nonfatal and six fatal access of opiate use : utility of morfinę, its metabolites, and their ratios in blood specimens. Forensic Toxicol. 2008, 26: 87-90.

15. Kłys M., Rojek S.: Usefulness of multi-parameter opiates-amphetamines-cocainics analysis in hair of drug users for the evaluation of an abuse profile by means of LC-APCl-MS-MS, J. Chromatogr. B. 2007, 854: 299-307.

16. Kłys M., Rojek S., Kulikowska J., Bożek E., Ścisłowski M: Usefulness of multiparameter opiate analysis in hair of drug users and victims of fatal poisonings. Przeg. Lek. 2005, 62: 585-590.

17. Kłys M., Rojek S., Kulikowska J., Bożek E.: Usefulness of multiple opiate and amphetamine analysis of hair segments under metadone therapy using LC-APCI-MS-MS. Forensic Toxicol. 2007, 25: 69-75.

18. Kłys M., Rojek S., Kowalski P., Rzepecka-Woźniak E.: Death of a female addict due to heroin and cocaine overdose: a case report with multiparameter evaluation. Forensic Toxicol. 2008. 26: 36-40.

19. Kłys M., Kowalski P.: Błąd diagnostyczny jako nadinterpretacja przesiewowego badania toksykologicznego przy niedostatecznej ocenie klinicznej. Arch. Med. Sąd. Kryminol. 2011, 61 (4): 213-300 .

20. Davenport-Hines R.: Odurzeni. Historia narkotyków 1500-2000. Warszawa 2006. 